10 years ESJ

Special edition

\title{
Analysis of Facial Expressions in Brazilian Sign Language (Libras)
}

\author{
Emely Pujolli da Silva, MSc, PhD \\ Universidade Estadual de Campinas, Brazil \\ Kate Mamhy Oliveira Kumada, MA, PhD \\ Universidade Federal do ABC, Brazil \\ Paula Dornhofer Paro Costa, MSc, PhD \\ Universidade Estadual de Campinas, Brazil
}

Doi: $10.19044 /$ esj.2021.v17n22p1

Submitted: 14 February 2020

Accepted: 10 December 2020

Published: 12 July 2021
Copyright 2021 Author(s)

Under Creative Commons BY-NC-ND

4.0 OPEN ACCESS

Cite As:

Silva, E. P.; Kumada, K. M. O.; Costa, P. D. P. (2021). Analysis of Facial Expressions in Brazilian Sign Language (Libras). European Scientific Journal, , ESJ, 17 (22), 1.

https://doi.org/10.19044/esj.2021.v17n22p1

\section{Abstract}

Brazilian Sign Language (in Portuguese, Libras) is a visuospatial linguistic system adopted by the Brazilian deaf communities as the primary form of communication. Libras are a language of minority groups, thus their research and production of teaching materials do not receive the same incentive to progress or improve as oral languages. This complex language employs signs composed of forms and hands movements combined with facial expressions and postures of the body. Facial expressions rarely appear in sign language literature, despite their being essential to this form of communication. Thereby, this research objectives are to present and discuss sub-categories of the grammatical facial expressions of Libras, with two specific objectives: (1) the building of an annotated video corpus comprehending all the categories identified in the literature of facial expressions in Brazilian sign language; (2) the application of Facial Action Coding System (FACS) (which has its origins as an experimental model in psychology) as a tool for annotating facial expressions in sign language. Ruled by a qualitative approach, the video corpus was carried out with nineteen Libras users (sixteen deaf and three hearing participants) who translated forty- 
three phrases from Portuguese to Libras. The records were later transcribed with the Eudico Linguistic Annotator software tool. From the analysis of the literature review, it was observed the need to classify facial expression as subcategories of lexical, as intensity, homonyms, and norm. It is believed that it is necessary to expand the studies on facial expressions, favoring their documentation and the description of their linguistic functions. Advances in this sense can contribute to the learning of Libras by deaf students and also by listeners who propose to act as teachers or as translators and interpreters of this language system.

Keywords: Sign language, Facial expressions, Libras, FACS

\section{Introduction}

In 2002, the Brazilian Sign Language (in Portuguese, Libras) was recognised by the Brazilian legal system as a form of communication and expression used by communities of deaf people in Brazil (Brazil, 2002).

Its recognition as a language forced the creation of bilingual deaf education policies. The need to train teachers, translators and interpreters shed light on the fact that despite its proven linguistic potential, there is a lack of formal and in-depth studies in many of its linguistic aspects. Being a language of minority groups, Libras does not receive the same attention or incentive in research, technology development, professional training or the production of teaching materials. Considering this, while linguistic studies on Libras date back to the eighties (Ferreira-Brito, 1986), its recognition as a language was a key factor to stimulate studies over this linguistic system and to support the bilingual deaf education policies that followed.

Sharing the same characteristics as other sign languages, Libras is a visuospatial language that uses manual markers as the main element of communication. Sign language linguistic studies adopt pre-defined parameters to describe a manual marker being: the hand configuration, the hand location, the orientation of the palm and the type of the movement performed by the hand while executing the sign. In addition, non-manual markers, like facial expressions and body movements, are also of great importance to communication in sign language (Ferreira-Brito, 1990, 1995).

Despite their central role in this linguistic system, non-manual expressions are one of the areas that receive little attention from Libras researchers. Even renowned courses responsible for training professionals for teaching, translation, and interpretation in Libras, admit the nonexistence of greater description of non-manual expressions (Souza, 2014).

In this context, the present work focuses on the study of facial expressions in Libras. In Libras, facial expressions are a fundamental part of 
communication since they may carry grammatical information, differentiate lexical items, participate in syntactic construction, contribute to intensification processes, or convey affective state. However, facial expressions in Libras are rarely covered in literature and few studies are focused on the syntactic functions of facial expressions in Libras (Souza, 2014). When the lexical structure is approached, its analysis is restricted to the intensification mode, leaving other aspects almost undocumented.

A key problem in the study of facial expressions in Libras is the lack of comprehensive annotated corpora to validate the facial expressions shown in the literature. As far as is known, there are only two corpora constructed for the study of facial expressions: Freitas et al. (2017) and Rezende et al. (2016). However, they are small and have fewer participants involved. In Freitas et al. (2017), ninety phrases were recorded with two hearing interpreters performing grammatical facial expressions for sentences. The videos were frame-based annotated with the presence or absence of facial expression without their specification. Rezende et al. (2016) recorded a hearing interpreter performing ten signs that have facial expressions. They were annotated with their own glosses. Among the challenges faced by the linguistic researchers, we highlight the lack of a broadly accepted standard for facial expression transcription, which prevents the conduction of objective studies.

This work presents two main contributions: (1) the building of an annotated video corpus comprehending all the categories identified in the literature of facial expressions in Brazilian sign language; (2) the application of Facial Action Coding System (FACS) (which has its origins as an experimental instrument in psychology) as a tool for annotating facial expressions in sign language. The paper also reviews the relevant literature of facial expressions in Libras. It is significant to note that the built corpus, including the annotation model proposed, can also leverage the research in NMEs for any sign language.

\section{The context of facial expressions in Libras}

In Libras, facial expressions can assume diverse functions and change widely (see examples of Libras' facial expressions in Figure 1). A facial expression may be combined with many different manual signs and the meaning of the same manual sign can vary significantly depending on the facial expression that accompanies it. The first step in the proposed analysis consisted of conducting a review of references dedicated to the description of Libras, with a focus on references that describe the production of non-manual expressions (NME). The definition of the relevant references for this study was done through interactions with deaf individuals, sign interpreters, and linguistic researchers. 

LANGUAGE AND EDUCATION: THINKING (AND DOING) OTHERWISE
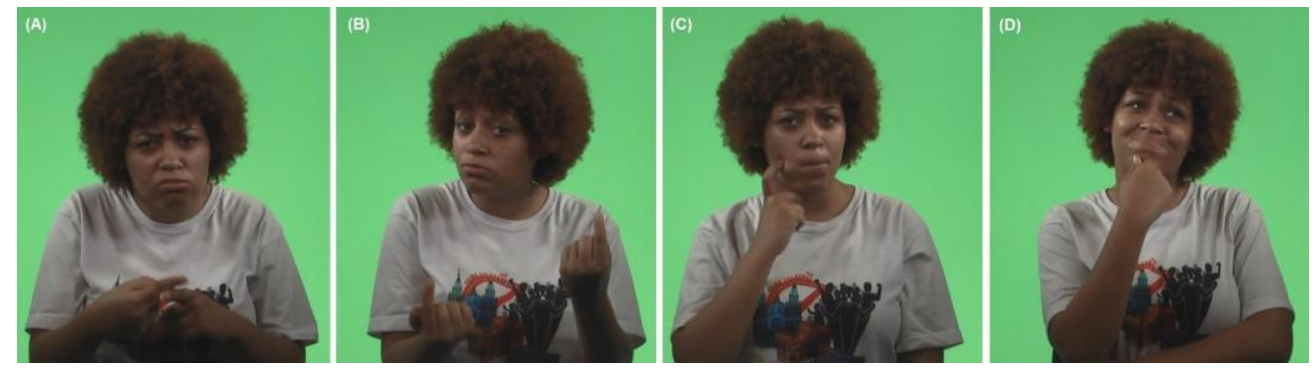

Figure 1. Examples of the variation of facial expressions in Libras. In images (A) and (B) it is presented two negative sentences, respectively, represented by the signs of "Why" and "Which". In the image (C), it can be observed the sign "Candy", in an affirmative sentence. In the image (D), there is the sign "Thinking" being presented in a doubt sentence. Source:

Corpus of the research itself.

In Libras discourse, facial expression can be separated into affective facial expressions and grammatical facial expressions. When facial expression conveys an idea of feeling and emotions, it is called Affective Facial Expression (AFE). They modulate the whole sentence, modifying the full meaning of a sequence of signs. So, an AFE may start before a specific sign and end after the sentence has been completed. For example, AFEs will appear when the subject communicates an enthusiastic event or describes a sad memory (Souza, 2014; Pimenta and Quadros, 2008).

Grammatical Facial Expressions (GFE) are typically presented at a certain point in a sentence or are associated with a particular manual sign. GFEs are divided by Pimenta and Quadros (2008) into sentence-related facial expressions and lexical facial expressions.

Sentence-related facial expressions, or (Grammatical Facial Expressions for Sentence, or GES), are the most mentioned in the literature and they help to define the type of the sentence that is being signaled (Pimenta, 2014; Freitas et al., 2014; Araujo, 2013; Quadros and Karnopp, 2008). GES markers that are expressed by the face and head movements is capable of discriminating the following types of sentences: 1) WH-question (WH): generally used for questions of type what, who, when, why, where and how; 2) Yes/No question (YN): used when the question being asked has a "yes" or "no" answer; 3) Doubt question (DQ): it is used to emphasize the information that will be supplied; 4) Topic (T): when one of the sentence's constituents is shifted to the beginning of the sentence; 5) Negation (N): used in negative sentences; 6) Assertion (A): used when making assertions; 7) Conditional clause (CC): used in a subordinate sentence to indicate a prerequisite to the main sentence; 8) Focus (F): used to highlight new information into the speech pattern; and 9) Relative clause (RC): used to provide more details about something. 
In its turn, lexical grammatical expressions are linked, as the name suggests, to the lexicon (Pimenta and Quadros, 2008). This research literature review showed that most studies restrict the analysis and description of lexical expressions to intensity expressions, or Grammatical Facial Expressions of Intensity (GEI).

GEIs constitute lexical components that mark the level of intensity on adverbs or adjectives (Quadros, 2008). For example, in Figure 2, variations of the same sign are observed associated with the word "expensive", shown in Figure 2.(A). In Figure 2.(B) the presented GEI changes the meaning of the original sign to "little expensive". In Figure 2.(C) the inflated cheeks, together with the same original sign, change the meaning to "very expensive".
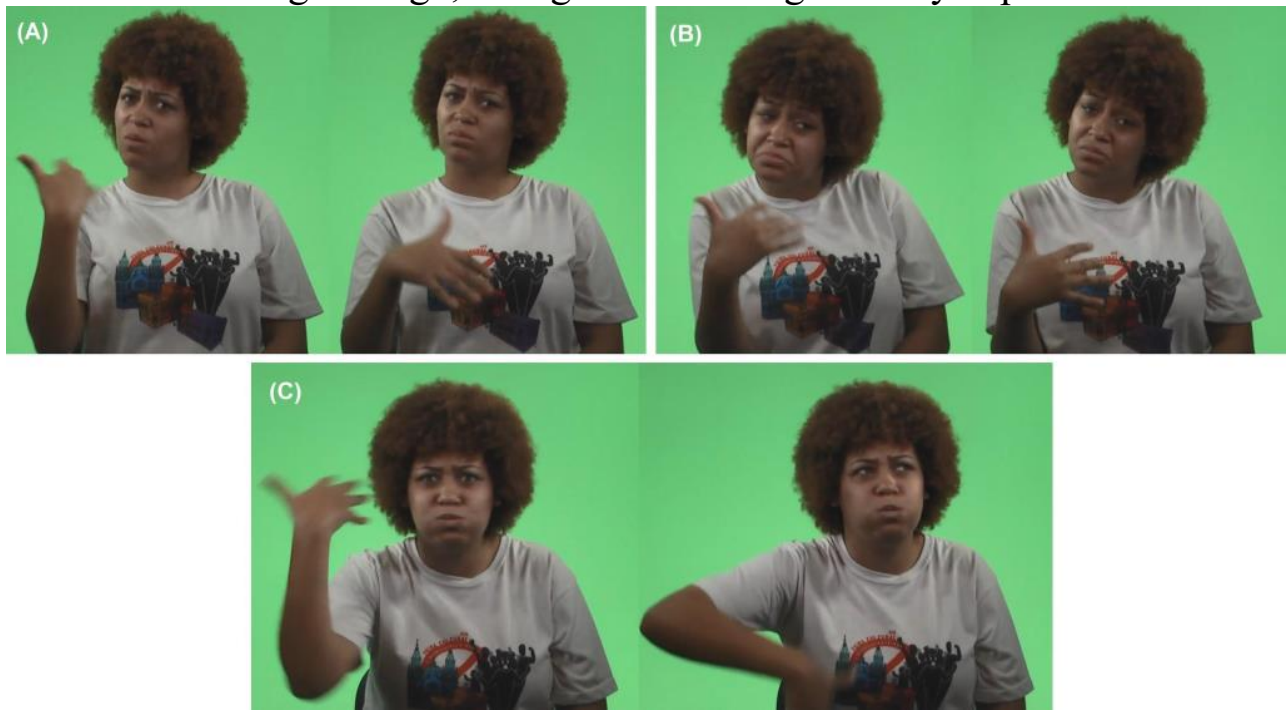

Figure 2. Examples of GEI (Grammatical Facial Expressions of Intensity).

The same sign, which means "expensive" (A), can be changed to "little expensive" (B) or "very expensive" (C), due to changes in facial expression and the amplitude of movements. Source: Corpus of the research itself.

It is noteworthy that, in the analysis of the literature found, two other subcategories of facial expressions that were not still classified. In this paper were called Grammatical Facial Expressions of Homonymy (from the Greek - homos: same, onoma: name - refers to words with identical forms but different meanings) and Grammatical Facial Expressions of Norm (i.e. by definition).

The Grammatical Facial Expressions of Homonymy, or GEH, differentiate signs with the same manual sign, helping to define the meaning of a sign. For example, Figures 3.(A) and 3.(B) show signs with the same manual sign, but with different facial expressions. In the first image (A) the sign means "Hotel", and in (B) the sign means "Motel". Their distinction is 
only based on one of the cheek actions. For this reason, we denote them GEH, because homonymous terms can be associated with subtle changes in the pronunciation of a word, such as the occurrence of these signs in Libras.

Finally, the Grammatical Facial Expressions of Norm (GEN) have a function of completing the manual sign. Without their corresponding GEN, the sign becomes incomplete and loses its meaning. For example, Figure 3.(C) shows the Libras sign for "Magnifying glass". If the facial expression is removed, as shown in 3.(D), the gesture has no meaning in Libras.

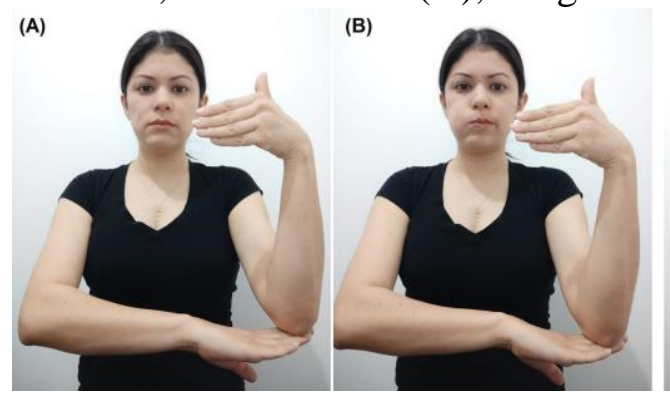

(C)

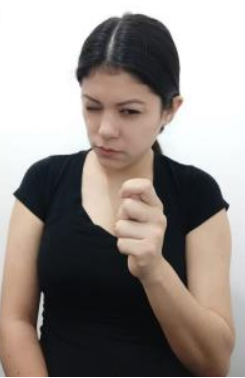

(D)

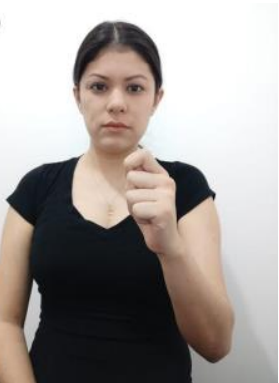

Figure 3. Performance of the signs in Libras using GEH (Grammatical Facial Expressions of Homonymy) and GEN (Grammatical Facial Expressions of Norm), respectively. In (A) the sign "Hotel" can be changed to "Motel" in (B), by the addition of eyes wide open and open mouth. Also, the sign "Magnifying glass" is performed in (C), and (D) a gesture without meaning. Source: Corpus of the research itself.

It is possible to notice that many of the non-manual articulators found in Libras are also used in other sign languages (da Silva et al., 2020). In Dachkovsky and Sandler (2009), it is argued that in the Israeli Sign Language (ISL), brow movement and squint is componential to provide intonational meaning, additional to characterising yes/no questions and the if-clause of conditionals. For the German SL (DGS), the mouth articulators: Lip pattern, tongue, and cheeks that are not related to the articulation of words can provide information redundant to gesturing to support differentiation of similar signs (Von Agris et al., 2008). Also, a change of head pose combined with the lifting of the eyebrows, corresponds to a subjunctive in DGS (da Silva et al., 2020). All these articulators' behaviours intersect with Libras facial expressions, and as it is for Libras, their study is necessary for a profound understanding of each language. However, there are not enough in-depth studies that focus on covering all the facial behaviour for particular sign languages, with the exception for American SL where Baker-Shenk (1983), Baker \& Padden (1978), Liddell (1978), Barrett et al (2019) and Benitez-Quiroz (2015) make significant contributions with analyses of facial articulators and their functions in speech. 


\section{Methodological procedures}

The present basic qualitative research was conducted through the analysis of facial expressions recorded in video of nineteen Libras users (sixteen deaf and three hearing individuals fluent in Libras), aged between eighteen and forty-four years old, with different levels of education and physical characteristics, all coming from the metropolitan region of the São Paulo city, Brazil.

The participants were invited to enunciate forty-three sentences in Libras, which were provided in written Portuguese. The sentences were created for this work and their transcriptions in glosses were made by the authors themselves. For the recording of the videos, all sentences written in Portuguese were used to elicit the statements of the informant. A video camera (Panasonic, AG HMC 70P) was used to record the participants, and a teleprompter monitor displaying the utterance was used to facilitate its production by the participants, who were capable of reading Brazilian Portuguese sentences.

Subsequently, the video materials were transcribed with the aid of the Eudico Linguistic Annotator (ELAN) software, a tool that has become increasingly common for annotating video material for linguistic studies, that the analysis of tracks created and named by the user himself (McCleary; Viotti and Leite, 2010).

Therefore, the methodological procedures adopted in the present work can be summarized as follows: (1) definition of a set of sentences that stimulate the production of all Libras facial expression categories found in the literature; (2) video recording of the sentences signalled by individuals who are fluent in Libras; (3) post-processing of video material and its annotation using FACS (Facial Action Coding System); (4) exploratory analysis of observed data.

\section{Transcription Model}

Among the challenges of studying facial expressions in Libras is the lack of a broadly accepted standard system for facial expression description, and consequently, transcription. William Stokoe Jr. system (Stokoe, 1960, 1978), Valerie Sutton SignWriting system (Sutton, 1995), Kyle and Woll (Kyle and Woll, 1985) are examples of sign representation systems. However, the deaf community has not widely accepted them as an orthographic instrument, and linguists have not assumed them as a tool for analysis. That is due to their very codified and graphic structure, which makes it hard to learn and understand the reading of the signs (McCleary; Viotti and Leite, 2010).

In general, to facilitate the reading of signs, a system of commented glosses is adopted. Glosses are words of a given oral language written in 
capital letters that represent manual signs of near sense. In this gloss system, the NMEs are annotated as comments, i.e. the sentence "He is not happy" would be transcribed as "HE NOT(head with negative movement) HAPPY(facial expression of joy)" (McCleary and Viotti, 2007). Ferreira-Brito (1995), Felipe (1998), Quadros (1999), McCleary and Viotti (2007), Santos (2002), Chan-Vianna (2003) and Finau (2004) adopted the glosses system for transcription of Libras.

The use of commented glosses for NME has disadvantages due to the limitation of glosses to represent the signal dynamics. Quadros (2004), Mccleary and Viotti (2007), and Anater (2012) are the only works that present a different approach for dealing with Libras' facial expression transcription. McCleary and Viotti (2007) and Anater (2012) describe facial expressions in a question using the tag <>qu, to indicate the presence of a grammatical nonmanual marker of question. For example, in the sentence "Where?" (in Portuguese, "Onde?"), the sentence annotation would be like $<\mathrm{ONDE}>\mathrm{qu}$. Because they adopt this strategy for narrowed focus analyzes, the generalization of their strategies may not be possible or become exhaustive for other researchers.

For the construction of a more embracing and systematic transcription model for Libras' facial expressions, this paper looks beyond the limits of linguistic studies, and borrows from the psychology field a more general way to describe facial expressions. In 1972, Ekman and Friesen introduced a coding system for a set of facial muscle movements that correspond to displayed facial expressions. The Facial Action Coding System (FACS) is built upon Action Units (AUs), which represent the muscular activity that produces momentary changes in facial appearance. To illustrate this, Figure 4 presents the facial expression of the sign "Happy" and the corresponding AUs involved in the performance of the sign. The production of each facial expression is unique, meaning that the facial articulators (the AUs) used to produce expressions are distinct from one another. Different facial articulators are identified with distinct AU numbers, as discussed later in Table 2. 


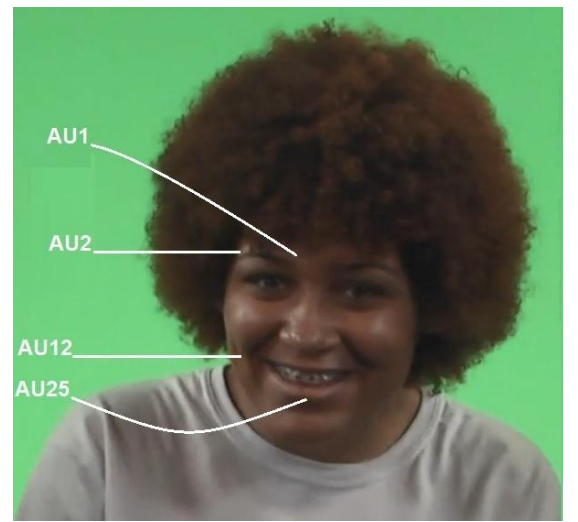

Figure 4. Facial expression of sign "Happy" and facial action unit code system. Source: Corpus of the research itself.

\section{Database and Annotation}

The methodology adopted to define the classes of facial expressions that should be present in the corpus, considered the fact that, in the literature, there are works focused on the GFE, but they are aimed at the GES class, leaving the GEI, GEH, and GEN classes without in-depth discussion.

The sentences used in the production of the corpus of the research itself are composed of eight neutral, three AFE, eleven GEI, eight GEH, and two GEN, resulting in a total of thirty-two sentences. All the phrases were constructed using neutral, higher, and lower intensity stimuli. This study was designed to compare the expressions used in both forms of intensification. Also, the construction of the phrases was aimed to obtain facial expressions that are not well documented, like cheeks blowing and apparent teeth.

During the record of the corpus, some signers did not recognize the Portuguese word used in a few sentences due to their lack of reading proficiency. For instance, the word "lawyer" was not recognized in the sentence "My teacher is a lawyer", and the term "magnifying glass" was not recognized in the sentence "Which is your magnifying glass?". In those cases, the interpreter presented the standard sign and explained their definition and meaning. As a result, two out of the three signers that asked for clarification made the same sign as the interpreter. Another remark is that not every signer produced precisely the same set of stimuli, an evidence of the linguistic variations present in this multilingual context (Silva and Kumada, 2013).

Video analysis was done in ELAN, a software tool that allows the creation of annotation tiers (Wittenburg et al., 2006). The total duration of the utterance was considered as the interval between the output from a neutral facial expression until the return to this position. In order to identify the different facial expressions, the annotation process was performed in thirteen tiers that describe the ENMs based on Quadros and Karnopp (2004), Pimenta 
and Quadros (2006) and Paiva et al. (2018), as described in Frame 1, including some annotation examples. The definition of possible filling values for each tier was obtained by combining the findings of Quadros and Karnopp (2004), Pimenta and Quadros (2006), McCleary et al. (2007), Anater, (2012), Capovilla et al. (2017), Kumada et al. (2016), De Martino et al. (2017), and Paiva et al. (2018) with our findings in the present work.

Table 1. List of tiers used in ELAN and their facial expressions possibilities

\begin{tabular}{|c|c|c|}
\hline Tier Name & Feature Description & Annotation Examples \\
\hline Portuguese & Statement in Portuguese & - \\
\hline Libras & $\begin{array}{|lll|}\begin{array}{l}\text { Statement } \\
\text { glosses }\end{array} & \text { transcribed in } \\
\end{array}$ & \\
\hline FACS & Action Units (AU) & $1,1+2,4,5,9,18 \ldots$ \\
\hline NMEs & $\begin{array}{l}\text { Presence of non-manual } \\
\text { expression }\end{array}$ & \\
\hline Sentence & Sentence Type Present & $\begin{array}{l}\text { Affirmative, Exclamatory, Negative, Topic, } \\
\text { Focus, Doubt, Relative, Question-WH, Yes } \\
\text { / No question }\end{array}$ \\
\hline Eyebrows & Eyebrows Shape & Frown, Raised eyebrows, Joined eyebrows \\
\hline Eyes & $\begin{array}{l}\text { Throw of eyes, narrowed or } \\
\text { rolled eyes }\end{array}$ & $\begin{array}{l}\text { Eyes turn left, Eyes turn right, Eyes up, Eyes } \\
\text { down, Wide, Closed, Tight }\end{array}$ \\
\hline Cheeks & Cheek Shape & Inflated, Contracted \\
\hline Mouth & Mouth Shape & $\begin{array}{l}\text { Open, Closed, Tight, Lips contracted, } \\
\text { Projected lips, Crooked mouth up, Crooked } \\
\text { mouth down }\end{array}$ \\
\hline Head & Head movement & $\begin{array}{l}\text { Head turn left, Head turn right, Head up, } \\
\text { Head down, Head tilt left, Head tilt right, } \\
\text { Tilted forward, Tilted up }\end{array}$ \\
\hline Eyelid & $\begin{array}{|lll|}\begin{array}{l}\text { Eyelid } \\
\text { blinking }\end{array} & \text { movements } & \text { or } \\
\end{array}$ & Open, Closed \\
\hline Tongue & Appearance of tongue & $\begin{array}{l}\text { Tongue in lisp position, Sibilant tongue, } \\
\text { Swinging alveolar tongue, Tongue bite, Tip } \\
\text { of the tongue touching the lips }\end{array}$ \\
\hline Teeth & Appearance of teeth & Apparent \\
\hline
\end{tabular}

Source: The research itself.

\section{Coding of Sign Language Facial Expressions using FACS}

Table 2 presents the proposed coding for the FACS tier of Table 1, that is applied to describe in detail the facial expressions found in the corpus.

In Table 2, the first column shows the standardized nomenclature found in the works of da Silva and Costa (2017), De Martino et al. (2016), Pimenta and Quadros (2006), Freitas et al. (2014), Capovilla et al. (2008). We highlight that different authors use different ways to describe the relevant NMEs in Libras. 
The second column of Table 2, represents the mapping between the nomenclature found in the literature and the facial muscular action as described in FACS (Ekman, 1978).

Finally, in the third column of Table 2, the codes for the action units (AU) are presented. However, it is important to note that some of Libras' facial expressions were not covered by the FACS coding system. This is the case of facial expressions in lines 4, 13, 15, 18, 19, 20, 21, 22, 23, 29, 31, 34 and 35. It is interesting to note that these facial expressions are not frequently observed in typical human interactions and they are particular to sign language communication. For these cases, the present work proposes an annotation code as a complement to the FACS system.

Table 2. Classification of Libras facial expressions associated with the facial action coding

\begin{tabular}{|c|c|c|c|}
\hline & $\begin{array}{c}\text { Facial expression } \\
\text { in Libras }\end{array}$ & $\begin{array}{l}\text { system } \\
\text { Muscular Action } \\
\text { Description }\end{array}$ & Annotation Code \\
\hline \multicolumn{4}{|c|}{ Upper Face } \\
\hline 1 & Joined eyebrows & $\begin{array}{l}\text { Inner brow raiser OR } \\
\text { frontalis (pars medialis) }\end{array}$ & AU1 \\
\hline 2 & Raised eyebrows & $\begin{array}{l}\text { Inner brow raiser AND } \\
\text { Outer brow raiser OR } \\
\text { frontalis (pars lateralis) }\end{array}$ & $\mathrm{AU} 1+\mathrm{AU} 2$ \\
\hline 3 & Frown & $\begin{array}{c}\text { Brow lowerer OR depressor } \\
\text { glabellae, depressor } \\
\text { supercilii, corrugator } \\
\text { supercilii }\end{array}$ & AU4 \\
\hline 4 & Left / Right eyebrow raised & $\begin{array}{c}\text { Outer brow raiser Left / } \\
\text { Right OR frontalis (pars } \\
\text { lateralis) }\end{array}$ & AU2L / AU2R \\
\hline 5 & Wide-open eyes & $\begin{array}{l}\text { Upper lid raiser OR levator } \\
\text { palpebrae superioris, } \\
\text { superior tarsal muscle }\end{array}$ & AU5 \\
\hline 6 & Nose wrinkle & $\begin{array}{l}\text { Nose wrinkler OR levator } \\
\text { labii superioris alaeque nasi }\end{array}$ & AU9 \\
\hline 7 & Slightly closed eyes & Orbicularis oculi muscle & AU42 \\
\hline 8 & Closed eyes & $\begin{array}{l}\text { Relaxation of Levator } \\
\text { palpebrae superioris }\end{array}$ & AU43 \\
\hline 9 & Left / Right eye closed & orbicularis oculi muscle & AU46 \\
\hline 10 & Look at the speaker & $\begin{array}{l}\text { Eyes positioned to look at } \\
\text { the other person }\end{array}$ & AU69 \\
\hline \multirow{2}{*}{11} & \multirow{2}{*}{ Direct the eyes } & Eyes turn left & AU61 \\
\hline & & Eyes turn right & AU62 \\
\hline
\end{tabular}


Special Edition: 5TH COLLOQUIUM OF THE RESEARCH GROUP BODY AND IMAGE IN

DISCOURSE: CECI N'EST PAS UNE PIPE \& 4TH SYMPOSIUM ON TRANSCULTURALITY, LANGUAGE AND EDUCATION: THINKING (AND DOING) OTHERWISE

\begin{tabular}{|c|c|c|c|}
\hline & & Eyes up & AU63 \\
\hline & & Eyes down & AU64 \\
\hline \multicolumn{4}{|c|}{ Lower Face } \\
\hline 12 & Crooked mouth up & $\begin{array}{l}\text { Lip corner puller OR } \\
\text { zygomaticus major }\end{array}$ & AU12 \\
\hline 13 & Crooked mouth up laterally & - & $12 \mathrm{R} / 12 \mathrm{~L}$ \\
\hline 14 & Crooked mouth down & $\begin{array}{c}\text { Lip corner depressor OR } \\
\text { depressor anguli oris (also } \\
\text { known as triangularis) AND } \\
\text { Chin raiser OR mentalis }\end{array}$ & AU15+AU17 \\
\hline 15 & $\begin{array}{c}\text { Crooked mouth down } \\
\text { laterally }\end{array}$ & - & $15 \mathrm{R} / 15 \mathrm{~L}$ \\
\hline 16 & Projected lips & $\begin{array}{c}\text { Lip pucker OR incisivii labii } \\
\text { superioris and incisivii labii } \\
\text { inferioris }\end{array}$ & AU18 \\
\hline 17 & Tongue in lips position & \multirow{5}{*}{ Tongue show } & AU19 \\
\hline 18 & $\begin{array}{c}\text { Swinging } \\
\text { alveolar }{ }^{1} \text { tongue }\end{array}$ & & AU86 \\
\hline 19 & Sibilant tongue $^{2}$ & & AU87 \\
\hline 20 & $\begin{array}{c}\text { Tip of the tongue touching } \\
\text { the lips }\end{array}$ & & AU88 \\
\hline 21 & Tongue bite & & AU16+AU19+AU22 \\
\hline 22 & Contraction of the upper lip & - & AU16+AU17+AU28 \\
\hline 23 & Contraction of the lower lip & - & AU17+AU22 \\
\hline 24 & Closed mouth & Orbicularis oris & AU24 \\
\hline 25 & Open mouth & $\begin{array}{c}\text { Lips part OR depressor labii } \\
\text { inferioris, or relaxation of } \\
\text { mentalis or orbicularis oris }\end{array}$ & AU25 \\
\hline 26 & Contracted lips & Lip suck OR orbicularis oris & AU28 \\
\hline 27 & semi-open mouth (blowing) & Cheek puff & AU33 \\
\hline 28 & Inflated cheeks & Cheek blow & AU34 \\
\hline
\end{tabular}

${ }^{1}$ In other words, open mouth and tongue in movement.

${ }^{2}$ This term refers to the region within the mouth in the inside margin of the upper central incisors. 
Special Edition: 5TH COLLOQUIUM OF THE RESEARCH GROUP BODY AND IMAGE IN

DISCOURSE: CECI N'EST PAS UNE PIPE \& 4TH SYMPOSIUM ON TRANSCULTURALITY, LANGUAGE AND EDUCATION: THINKING (AND DOING) OTHERWISE

\begin{tabular}{|c|c|c|c|}
\hline 29 & $\begin{array}{l}\text { Only Right / Left cheek } \\
\text { inflated }\end{array}$ & - & AU34R / AU34L \\
\hline 30 & Contracted cheeks & Cheek suck & AU35 \\
\hline 31 & Clenched teeth & $\begin{array}{l}\text { Lip funneler OR orbicularis } \\
\text { oris AND Jaw clencher }\end{array}$ & $\begin{array}{c}\text { AU16+AU22+AU25+A } \\
\text { U31 }\end{array}$ \\
\hline 32 & Mouth movement & Speech & AU50 \\
\hline 33 & Chewing & Jaw movement & AU81 \\
\hline 34 & Snap of the lips & - & AU26+AU28 \\
\hline 35 & $\begin{array}{l}\text { Run the tongue against the } \\
\text { lower part of the cheek }\end{array}$ & - & AU19+AU20 \\
\hline \multicolumn{4}{|c|}{ Head } \\
\hline 36 & Neutral & - & AU0 \\
\hline \multirow{2}{*}{37} & \multirow{2}{*}{ Head to the side } & Head turn left & AU51 \\
\hline & & Head turn right & AU52 \\
\hline \multirow{2}{*}{38} & \multirow{2}{*}{ Head Up and down } & Head up & AU53 \\
\hline & & Head down & AU54 \\
\hline \multirow{2}{*}{39} & \multirow{2}{*}{ Tilt to the side } & Head tilt left & AU55 \\
\hline & & Head tilt right & AU56 \\
\hline 40 & Quick nod & $\begin{array}{c}\text { Forward lean OR Head } \\
\text { forward } \\
\end{array}$ & AU57 \\
\hline 41 & $\begin{array}{c}\text { Brief and upward movement } \\
\text { of the head }\end{array}$ & Tilt back OR Head back & AU58 \\
\hline 42 & Balancing sideways (no) & Head shake back and forth & AU84 \\
\hline 43 & Balance back and forth (yes) & Head nod up and down & AU85 \\
\hline
\end{tabular}

Source: The research itself.

\section{Results}

The process of annotating each sentence in ELAN took approximately 60 to 90 minutes. It requires a well trained professional, capable of detecting and identifying even the most subtle changes in the face. Despite the great effort to obtain such a corpus, it is important to emphasize the great relevance of this type of annotation work, since it enables a data-driven approach to the analysis of patterns and frequencies in sign language studies.

Our preliminary analysis showed, for example, that in GEH sentences, in order to obtain the change in the meaning, the subjects oscillated between showing a different manual sign or not presenting facial expression. For instance, in the sentence "Tomorrow I can't", the intended sign is the negative of "to can". Frequently, the expected NME would be a "head shake" combined 
with a manual sign of "busy". Five participants played as expected. However, two subjects made the same manual sign as "power" combined with "head shake". In addition, one person did a completely different manual sign, in which the sign "to leave" was used combined with "head shake". Similar discrepancy between the expected behavior and the produced sign by the participants was observed in the signalization of $9 \%$ of the sentences.

It was observed that FACS helped to easily count and classify the facial expressions in the corpus. In summary, having a standard, language-agnostic coding and transcription model characterizes a powerful tool to investigate the ordering of the shapes of the facial expressions, their frequency, their dynamics in the sentence, and it also enables the conduction of comparative studies among subjects and sign languages.

\section{Conclusion}

The education of the deaf is integrated into the study of minority bilingual education, a subarea of Applied Linguistics that conducts studies on minority contexts, minoritized and invisible minorities (Skutnabb-Kangas, 1981; Cavalcanti, 1999; Kumada; Cavalcanti and Silva, 2019).

The discussion about linguistic aspects involving Libras' lexical facial expressions still represents a gap in the area, with few productions and/or disclosures in this area. Considering that the discussion about Libras and the bilingual context of minorities falls within the applied linguistic field of transdisciplinary or "undisciplinary" (Moita Lopes, 2008; Lopes, 2008), the dialogue with the psychology of Ekman and Friesen (1972) becomes coherent, as well as the contribution of other areas of knowledge.

As far as is known, there are only two corpora constructed for the study of Libras' facial expression: Freitas et al. (2017) and Rezende et al. (2016). However, they are small and have fewer participants involved. The corpus introduced in this work represents a more in-depth and embracing collection of Libras' facial expression samples.

The article also reported the transcription process and the production of Libras' corpus focused on the different facial expression categories. Also, a coding system for facial expressions in Libras, inspired by FACS, was introduced. The proposed approach not only validated some known nonmanuals but also helped to identify a large variety of previously unsuspected facial expressions. This work showed that Brazilian sign language comprehends a set of facial expressions that is greater than those coded by FACS.

As future work, an in-depth analysis of the corpus, based on the facial expression codes is planned. In addition, given the built corpus, it is planned 
to train a machine learning model that will be able to help annotators to identify the action unit codes present in the videos.

Also, new modifications arising from the natural evolution of the language must be incorporated into our system throughout the next few years. Indeed, a more solid registry work and the knowledge of our solution compose a fundamental step in advancing linguistic Libras studies.

\section{References:}

1. Anater, G. I. P. (2012). As marcações linguísticas não-manuais na aquisição da língua de sinais brasileira (LSB): um estudo de caso longitudinal (Masters dissertation, UFSC).

2. Araujo, A. D. S. D. (2013). As expressões e as marcas não-manuais na Lingua de Sinais Brasileira (Masters dissertation, UnB).

3. Baker C \& Padden C (1978). Focusing on the nonmanual components in American Sign Language. In P. Siple (Ed.) Understanding language through sign language research (pp. 27-57). Academic Press.

4. Baker-Shenk C (1983). A micro-analysis of the nonmanual components of questions in American Sign Language. (Doctoral dissertation) University of California at Berkeley.

5. Barrett, L. F., Adolphs, R., Marsella, S., Martinez, A. M., \& Pollak, S. D. (2019). Emotional Expressions Reconsidered: Challenges to Inferring Emotion From Human Facial Movements. Psychological Science in the Public Interest, 20(1), 1-68.

6. Benitez-Quiroz, C. F. (2015). A Computational Study of American Sign Language Nonmanuals (Doctoral dissertation, The Ohio State University).

7. BRASIL (2002). Federal Law no 10.436 from 24 of April of 2002.

8. Capovilla, F. C., Raphael, W. D., \& Mauricio, A. C. (2008). Novo dicionário enciclopédico ilustrado trilíngue da Língua de Sinais Brasileira (Novo Deit-Libras). Transtornos de aprendizagem: da avaliação à reabilitação, 165-177.

9. Capovilla, F. C., Raphael, W. D., Martins, A. C., \& Temoteo, J. G. (2017). Dicionário da Língua de Sinais do Brasil: a Libras em suas mãos. EDUSP.

10. Cavalcanti, M. C. (1999). Estudos sobre educação bilíngüe e escolarização em contextos de minorias lingüísticas no Brasil. DELTA: Documentação de Estudos em Lingüística Teórica e Aplicada, 15(SPE), 385-417.

11. Chan-Vianna, A. C. (2003). Aquisição de português por surdos: estruturas de posse (Masters dissertation, University of Brasília).

12. Dachkovsky, S., \& Sandler, W. (2009). Visual intonation in the 
prosody of a sign language. Language and speech, 52(2-3), 287-314. 13. da Silva, E. P.; Costa, P. D. P. (2017). Recognition of non-manual expressions in brazilian sign language. In: 12th IEEE International Conference on Automatic Face and Gesture Recognition. At: Washington DC, USA.

14. da Silva, E.P., Costa, P.D.P., Kumada, K.M.O., De Martino, J.M., Florentino, G.A. (2020). Recognition of affective and grammatical facial expressions: a study for Brazilian sign language. In: Proceedings of the 16th European Conference on Computer Vision (ECCV), Sign Language Recognition, Translation and Production (SLRTP) Workshop.

15. De Martino, J. M., Silva, I. R., Bolognini, C. Z., Costa, P. D. P., Kumada, K. M. O., Coradine, L. C., \& Angare, L. M. G. (2017). Signing avatars: making education more inclusive. Universal Access in the Information Society, 16(3), 793-808.

16. de Oliveira, C. L. (2008). Um apanhado teórico-conceitual sobre a pesquisa qualitativa: tipos, técnicas e características. Travessias, v. 2 (3).

17. De Quadros, R. M., \& Karnopp, L. B. (2009). Língua de sinais brasileira: estudos lingüísticos. Artmed Editora.

18. Ekman, P; Friesen, W. V., \& Ellsworth, P. (1972). Emotion in the human face: guide-lines for research and an integration of findings. Pergamon.

19. Ekman, P. (1978). Facial action coding system. Consulting Psychologists Press.

20. Felipe, T. (1988). O signo gestual-visual e sua estrutura frasal na língua dos sinais dos centros urbanos do Brasil (LSCB). (Masters dissertation, UFPE).

21. Felipe, T. (1998). A relação sintático-semântica dos verbos na língua brasileira de sinais - Libras. (Doctoral dissertation, UFRJ).

22. Ferreira-Brito, L. (1986). Integração social do surdo. Trabalhos em Linguística Aplicada, 7.

23. Ferreira-Brito, L. (1990). Uma abordagem fonológica dos sinais da LSCB. Informativo Técnico-Científico do INES, Rio de Janeiro, 1(1), 20-43.

24. Ferreira-Brito, L. (1995). Por uma gramática de línguas de sinais. Tempo Brasileiro.

25. Finau, R. (2004). Os sinais de tempo e aspecto na Libras. (Doctoral dissertation, UFPR).

26. Freitas, F. A.; Peres, S. M.; Lima, C. A.; \& Barbosa, F. V. (2017). Grammatical facial expression recognition in sign language discourse: 
a study at the syntax level. Information Systems Frontiers, 19(6), 12431259.

27. Kumada, K. M. O.; Silva, I. R.; de Martino, J. M.; Costa, P. D. P.; Rosa, L. A.; Benetti, A. B. (2016). Desafios da Aprendizagem de Português/Libras por meio da Tradução de Material Didático com uso de Avatares Expressivos: Foco na Criação de Conceitos para o Ensino de Ciências. I Congresso Internacional de Educação Especial $e$ Inclusiva/XII Jornada de Educação Especial, 18-20 Maio, Marília.

28. Kyle, J. G. \& Woll, B. (1985). Sign language. Cambridge University Press.

29. Liddell, S. K. (1978). Nonmanual signals and relative clauses in american sign language. Understanding language through sign language research, Academic Press New York, p.59-90.

30. McCleary, L., \& Viotti, E. (2007). Transcrição de dados de uma língua sinalizada: um estudo piloto da transcrição de narrativas na lingua de sinais brasileira (LSB). Bilingüismo dos surdos: Questões lingüísticas e educacionais. Cânone Editorial, 73-96.

31. McCleary, L., Viotti, E., \& de Arantes Leite, T. (2010). Descrição das línguas sinalizadas: a questão da transcrição dos dados. ALFA: Revista de Linguística, 54(1).

32. Moita Lopes, L. P. D. (2008). Gêneros e sexualidades nas práticas discursivas contemporâneas: desafios em tempos queer. Identidades de gênero e práticas discursivas. Campina Grande: EDUEP, 13-18.

33. Lopes, L. P. D. M. (2008). Inglês e globalização em uma epistemologia de fronteira: ideologia lingüística para tempos híbridos. DELTA: Documentação de Estudos em Lingüística Teórica e Aplicada, 24(2), 309-340.

34. Paiva, F. A. S., Barbosa, P. A., De Martino, J. M., Will, A. D., dos Santos Oliveira, M. R. N., Silva, I. R., \& Xavier, A. N. (2018). Análise do papel das expressões não manuais na intensificação em libras. DELTA: Documentação e Estudos em Linguística Teórica e Aplicada, 34(4).

35. Pimenta, N., \& Quadros, R. M. D. (2006). Curso de LIBRAS 1. Rio de Janeiro: LSB vídeo.

36. Rezende, T. M. (2016). Aplicação de técnicas de inteligência computacional para análise da expressão facial em reconhecimento de sinais de libras. (Masters dissertation, UFMG)

37. Santos, D. V. (2002). Estudos de línguas de sinais: Um contexto para a análise da língua brasileira de sinais (Libras) (Doctoral dissertation, UFRJ).

38. Silva, I. R., \& Kumada, K. M. O. (2013). Representações sobre o 
contexto multilíngue da surdez. Interdisciplinar-Revista de Estudos em Lingua e Literatura, 19.

39. Skutnabb-Kangas, T. (1981). Bilingualism or not: The education of minorities (Vol. 7). Multilingual Matters.

40. Souza, S. X. (2014). Reflexões comparativas sobre procedimentos tradutórios ao português de poemas em língua brasileira de sinais. Mutatis Mutandis: Revista Latinoamericana de Traducción, 7(1), 168190.

41. Stokoe Jr, W. C. (2005). Sign language structure: An outline of the visual communication systems of the American deaf. Journal of deaf studies and deaf education, 10(1), 3-37.

42. Stokoe, W. C. (1980). Sign language structure. Annual Review of Anthropology, 9(1), 365-390.

43. Sutton, V. (1995). Lessons in sign writing. SignWriting.

44. Von Agris, U., Knorr, M., Kraiss, K.F. (2008). The significance of facial features for automatic sign language recognition. In: 8th IEEE International Conference on Automatic Face \& Gesture Recognition, 2008 (FG'08). pp. 1-6. IEEE.

45. Wittenburg, P., Brugman, H., Russel, A., Klassmann, A., \& Sloetjes, H. (2006). ELAN: a professional framework for multimodality research. In 5th International Conference on Language Resources and Evaluation (LREC 2006) (pp. 1556-1559). 